\title{
Synthesis, characterization and cytotoxic activity of palladium (II) dithiocarbamate complexes with $\alpha, \omega$-diamines
}

\author{
Diego Montagner ${ }^{\mathrm{a}, *}$, Cristina Marzano ${ }^{\mathrm{b}}$, Valentina Gandin ${ }^{\mathrm{b}}$ \\ a Dipartimento di Scienze Chimiche dell' Università, Via Marzolo 1, 35131 Padova, Italy \\ ${ }^{\mathrm{b}}$ Dipartimento di Scienze Farmaceutiche dell' Università, Via Marzolo 5, 35131 Padova, Italy
}

\section{A R T I C L E I N F O}

\section{Article history:}

Received 12 May 2011

Received in revised form 12 July 2011

Accepted 20 July 2011

Available online 28 July 2011

Dedicated to Dr. Elena Bertacco, a Ph. D. student of our group recently deceased.

\section{Keywords:}

Palladium complexes

Diamines

Dinuclear complexes

Cytotoxicity

\begin{abstract}
A B S T R A C T
The polymeric $[\mathrm{PdCl} \text { (dithiocarbamate) }]_{n}$ complexes, in which the ligand ion is dimethyldithiocarbamate (DMDT), pyrrolidine dithiocarbamate (PyDT, $\left(\mathrm{CH}_{2}\right)_{4} \mathrm{NCS}_{2}^{-}$) and sarcosine ethyl ester dithiocarbamate (ESDT, $\mathrm{EtO}_{2} \mathrm{CCH}_{2} \mathrm{~N}\left(\mathrm{CH}_{3}\right) \mathrm{CS}_{2}{ }^{-}$), have been reacted with chelating diamines, like ethylenediamine (en) or 1,3-diaminopropane (dap) and long chain diamines, like 1,4-diaminobutane (dab) or 1,7-diaminoheptane (dah). The reaction products depend on either diamine chain length or molar ratio. By operating at $\mathrm{PdCl}$ (dithiocarbamate)/diamine molar ratio 1:1 chelating diamines yielded the ionic [Pd(dithiocarbamate)(diamine)]Cl species (diamine $=$ en or dap), whereas with long chain diamines species of the type $[\mathrm{Pd}(\text { dithiocarbamate })(\text { diamine })]_{n} \mathrm{Cl}_{n}$ (diamine $=$ dab or dah) were obtained, in which each $\mathrm{Pd}$ (dithiocarbamate) ${ }^{+}$unit binds to the $\mathrm{NH}_{2}$ group of two different molecules, in a network of bridging diamines. At molar ratio 1:0.5, the long chain diamines yielded the binuclear $\left[\mathrm{Pd}_{2} \mathrm{Cl}_{2}\right.$ (dithiocarbamate) ${ }_{2}($ diamine $\left.)\right]$ complexes (diamine $=$ dab or dah), whereas exchange reactions take place generally in the presence of en or dap. The reaction trend is described on the basis of IR and proton NMR spectra. The new dithiocarbamate complexes were preliminarily tested for their cytotoxicity on human cancer cells.
\end{abstract}

(c) 2011 Elsevier B.V. All rights reserved.

\section{Introduction}

Recent advances on platinum-based drugs concern the improvement of the antitumour properties of cisplatin and carboplatin by appropriate changes in either leaving or N-donor groups, which could influence DNA interactions and drug metabolism [1]. Several series have been synthesized, in which the non-leaving ligands are generally mono- or diamines, the leaving groups being chloride ions or carboxylates, whereas reports on the palladium analogues are scanty. The main purpose of several researches is to overcome toxicity and cross resistance induced by cisplatin and analogues. Small changes in ligand substituents can influence the biological activity of the complexes, as for the chain length in $\mathrm{N}$-alkyl-ethylenediamine derivatives of the type [cis- $\left.\mathrm{PtCl}_{2}\left\{\mathrm{H}_{2} \mathrm{NCH}_{2} \mathrm{CH}_{2} \mathrm{NH}\left(\mathrm{CH}_{2}\right)_{n} \mathrm{CH}_{3}\right\}\right]$ $(n=8-15)$ and $\left[\left\{c i s-\mathrm{PtCl}_{2}\left(\mathrm{H}_{2} \mathrm{NCH}_{2} \mathrm{CH}_{2} \mathrm{NH}\right)\right\}_{2}\left(\mathrm{CH}_{2}\right)_{n}\right](n=6-12)$, the latter containing a bridging aliphatic chain between the $\mathrm{PtCl}_{2} \mathrm{~N}_{2}$ centres [2]. Propanediamine derivatives of the type $\left[\mathrm{PtCl}_{2}(N-\right.$ benzyl-1,3-propanediamine $)_{2}$ ] have been reported as potential antitumour agents [3], whereas platinum complexes with 2,2'bipyridines, in which have been inserted acridine tails, allow to examine the combination of covalent attack to DNA (through the $\mathrm{PtCl}_{2} \mathrm{~N}_{2}$ moiety) and intercalation effect (by the tail chromophore)

\footnotetext{
* Corresponding author. Tel.: +39 49 8275172; fax: +39 498275161 .

E-mail address: diego.montagner@unipd.it (D. Montagner).
}

[4]. Kinetics of ligand replacement by ethylenediamine in palladium complexes containing either 2,2'-bipyridine and substituted ethylenediamines depends on the alkyl groups at the $\mathrm{N}$-atom, which influence the hydrogen bond network with water oxygen [5].

Dinuclear species like $\left.\left[\mathrm{M}_{2} \text { (diamine)(triazolopyrimidinato }\right)_{2}\right]^{2+}$ ( $\mathrm{M}=\mathrm{Pd}$ or Pt; diamine $=2,2^{\prime}$-bipyridil or 1,10 -phenantroline $)$ contain two nearly parallel $[\mathrm{M}(\text { diamine })]^{2+}$ units, the $\mathrm{M}$ atoms being linked by two nitrogen atoms of each bridging pyrimidinato anion [6]. Binuclear and trinuclear platinum complexes are actually under study as potent second generation drugs, whose interaction with DNA differs from that of cisplatin and depends on geometry, leaving groups and bridging ligands, generally polyamines [7]. Polyamines are present in human cells and in tumours, and they can influence RNA expression through polyamine-dependent protein [8,9]. The trinuclear complex $\left[\mathrm{Pt}\left(\mathrm{NH}_{3}\right)_{2} \mathrm{Cl}\left\{\mathrm{NH}_{2}\left(\mathrm{CH}_{2}\right)_{6}\right.\right.$ $\left.\left.\mathrm{NH}_{2}\right\} \mathrm{Pt}\left(\mathrm{NH}_{3}\right)_{2}\left\{\mathrm{NH}_{2}\left(\mathrm{CH}_{2}\right)_{6} \mathrm{NH}_{2}\right\} \mathrm{Pt}\left(\mathrm{NH}_{3}\right)_{2} \mathrm{Cl}\right]^{4+}$, which contains three trans-diaminoplatin units linked by two diaminohexane molecules, is now in clinical trial, owing to the ability to overcome cisplatin resistance [10]. In order to enhance the therapeutic index, dinuclear complexes in which the bridging ligands are spermidine, or analogues containing carbamato groups, have been studied, obtaining species of remarkable activity [11]. Substitution of ammonia with pyridine or picolines in dinuclear alkyldiamine platinum complexes causes lower cytotoxicity, notwithstanding a DNA binding kinetics superior to cisplatin [12]. Attempts toward more effective 

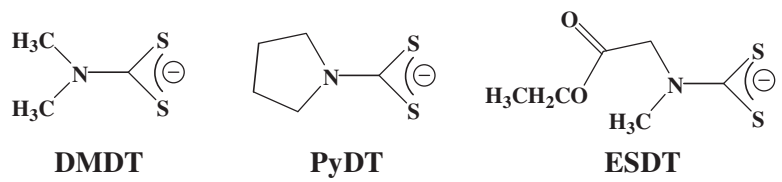

Chart 1.

polynuclear drugs consist in the insertion of functionalized groups in bridging polyamines, as amido-residues in bimetallic palladium and platinum complexes [13].

As a general remark, the interaction mode of polynuclear complexes with DNA could follow a different way than cisplatin, whose attack occurs preferentially between the N7 atom of two adjacent guanine residues. The fact that many S-donor sites are also present could suggest competition among $\mathrm{N}$ and $\mathrm{S}$ sites as determinant in drug behaviour, metal coordination to sulfur inducing possibly the formation of a drug reserve in the cell [14]. Sulfur donors, generally thiols, are administered in combination with cisplatin, in order to reduce renal damages [15-20]. The chemoprotective action of sulfur containing molecules explains the attention to their effect on Pd-N and Pt-N bonds. Glutathione has been found to be the strongest nucleofile toward palladium complexes with tridentate $\mathrm{N}$-donors, whereas diethyldithiocarbamate was the most effective rescue agent against cisplatin in respect to thiourea, thiosulfate or glutathione [21,22].

An alternative way to modulate activity and toxicity of platinum-based drugs concerns the design of new molecules containing both $\mathrm{N}$ and $\mathrm{S}$ donor sites [23-25]. As regards dithiocarbamates, the mixed complexes $\left[\mathrm{M}\left(\mathrm{S}_{2} \mathrm{CNEt}_{2}\right)(\mathrm{L})\right] \mathrm{NO}_{3}(\mathrm{M}=\mathrm{Pd}$ or Pt; $\mathrm{L}=2,2^{\prime}$-bipyridil or 1,10-phenantroline) were found active toward leukemic cells [26]. In this line we reported various palladium and platinum complexes containing either dithiocarbamate and amine moieties, of general formula [ $\mathrm{MCl}$ (dithiocarbamate)(amine)] and $\left.[\mathrm{M} \text { (dithiocarbamate)(amine) })_{2}\right] \mathrm{Cl}[27,28]$. Among them, some species in which dithiocarbamate was ESDT $\left(\mathrm{EtO}_{2} \mathrm{CCH}_{2}\left(\mathrm{CH}_{3}\right) \mathrm{NCS}_{2}{ }^{-}\right)$ (Chart 1), an ion containing the sarcosine moiety, gave interesting results when tested against human cancer cells [29], the most efficacy being the [PtCl(ESDT)(pyridine)] complex [30,31]. This compound has shown cytotoxic efficacy, ability to overcome cisplatin resistance and low toxicity $[30,31]$ whereas $[\mathrm{PdCl}(\mathrm{ESDT})]_{n}$ was toxic and scarcely active [30]. We thought then of interest to extend the study to polynuclear diamino-bridged complexes containing $\mathrm{MCl}$ (dithiocarbamate) residues. As a first study, this paper reports the interaction of the polymeric $[\mathrm{PdCl}(\text { dithiocarbamate })]_{n}$ species with diamines. Dithiocarbamate ions were $\mathrm{Me}_{2} \mathrm{NCS}_{2}{ }^{-}$ (DMDT), $\left(\mathrm{CH}_{2}\right)_{4} \mathrm{NCS}_{2}{ }^{-}$(PyDT) and $\mathrm{EtO}_{2} \mathrm{C}\left(\mathrm{CH}_{2}\right) \mathrm{N}\left(\mathrm{CH}_{3}\right) \mathrm{CS}_{2}{ }^{-}$(ESDT) and the amines were ethylenediamine (en), 1,3-diaminopropane (dap), 1,4-diaminobutane (dab) and 1,7-diaminoheptane (dah).

Although recent studies are focused on the interaction of multinuclear platinum complexes linked by flexible diamino alkanes, mixed platinum and palladium complexes of the type $\left[\left\{\text { trans- } \mathrm{PtCl}\left(\mathrm{NH}_{3}\right)_{2}\right\}_{2}-\mu-\left\{\right.\right.$ trans- $\left.\left.\mathrm{Pd}\left(\mathrm{NH}_{3}\right)_{2}-\left(\mathrm{H}_{2} \mathrm{~N}\left(\mathrm{CH}_{2}\right)_{n} \mathrm{NH}_{2}\right)_{2}\right\}\right] \mathrm{Cl}_{4} \quad(n=$ 4-7) have been found to exhibit significant anticancer activity against ovarian cancer cell lines [32-35]. Those species contain a central trans-Pd( $\left(\mathrm{NH}_{3}\right)_{2}$ unit, which is bound to two trans-Pt( $\left.\mathrm{NH}_{3}\right)_{2}$ units by bridging diamines, the trinuclear complex assuming a +4 charge. For this reason either neutral or ionic species, containing dithiocarbamate and chelating or bridging diamines, were evaluated for their cytotoxicity on human tumour cell lines.

\section{Experimental}

Elemental analyses were carried out on a Fisons EA1108 CHNSO microanalyser. IR spectra were recorded on Nicolet 5SXC FT-IR and 20F Far-IR spectrometers, as either Nujol mulls between $\mathrm{KBr}$ and polyethylene discs or $\mathrm{KBr}$ pellets. NMR spectra were measured using a Bruker DRX 300 (ppm; internal standard, TMS). Thermogravimetric data in air were obtained on Netzsch STA 449 thermoanalytical equipment (flux rate, $50 \mathrm{~cm}^{3} \mathrm{~min}^{-1}$; heating rate, $5{ }^{\circ} \mathrm{Cmin}^{-1}$; reference material $\mathrm{Al}_{2} \mathrm{O}_{3}$ ). The weight of the samples in the crucible was about $15-25 \mathrm{mg}$.

\subsection{Reagents}

Palladium chloride, $\mathrm{NBu}_{4} \mathrm{Cl}$, ethylenediamine (en), 1,3-diaminopropane (dap), 1,4-diaminobutane (dab), and 1,7-diaminoheptane (dah) and DMSO- $d_{6}$ were used as supplied (Aldrich products).

\subsection{Starting materials}

The $[\mathrm{PdCl}(\mathrm{ESDT})]_{n}$ complex $\left(\mathrm{ESDT}=\mathrm{EtO}_{2} \mathrm{CH}_{2} \mathrm{~N}\left(\mathrm{CH}_{3}\right) \mathrm{CS}_{2}{ }^{-}\right.$) was prepared by thermal degradation of solid samples of $\left[\mathrm{PdCl}_{2}\right.$ $(\mathrm{ESDTM})]\left(\mathrm{ESDTM}=\mathrm{EtO}_{2} \mathrm{CH}_{2} \mathrm{~N}\left(\mathrm{CH}_{3}\right) \mathrm{CS}_{2} \mathrm{CH}_{3}\right)$ in oil bath $\left(120^{\circ} \mathrm{C}\right)$ under reduced pressure $[36,37]$. The $[\mathrm{PdCl}(\mathrm{PyDT})]_{n}$ analogue was obtained by heating the parent $\left[\mathrm{PdCl}_{2}(\mathrm{PyDTM})\right]$ species (PyDTM $\left.=\left(\mathrm{CH}_{2}\right)_{4} \mathrm{NCS}_{2} \mathrm{CH}_{3}\right)$ in oil bath at $210^{\circ} \mathrm{C}$ [38]. Evolution of methyl chloride takes place, the orange initial product turning into a pink powder, the colour being common to all the examined intermediates. The $[\mathrm{PdCl}(\mathrm{DMDT})]_{n}$ intermediate was prepared either by thermal degradation of $\left[\mathrm{PdCl}_{2}(\mathrm{DMDTM})\right]\left(\mathrm{DMDTM}=\left(\mathrm{CH}_{3}\right)_{2} \mathrm{NCS}_{2^{-}}\right.$ $\mathrm{CH}_{3}$; oil bath at $150-170{ }^{\circ} \mathrm{C}$ ) [39], or by reaction of $\mathrm{PdCl}_{2}$ with DMDTB (DMDTB $=\left(\mathrm{CH}_{3}\right)_{2} \mathrm{NCS}_{2}-\mathrm{Ph}$ ) in dichloromethane [38].

The $\left[\mathrm{PdCl}_{2}\right.$ (dap)] complex has been prepared by reacting $\mathrm{PdCl}_{2}$ $(1.0 \mathrm{mmol})$ and dap $(1.0 \mathrm{mmol})$ in $\mathrm{CH}_{3} \mathrm{CN} / \mathrm{CHCl}_{3}$ (3:1 vol/vol, 1 day with stirring). Yield, $61 \%$. The pale yellow solid was filtered, washed with $\mathrm{CHCl}_{3}$ and dried under reduced pressure. The $\left[\mathrm{Pd}(\mathrm{dap})_{2}\right] \mathrm{Cl}_{2}$ species has been prepared by reaction of $\mathrm{PdCl}_{2}$ $(1.0 \mathrm{mmol})$ with dap $(4.0 \mathrm{mmol})$ in $\mathrm{CHCl}_{3}\left(15 \mathrm{~cm}^{3} ; 8\right.$ days $)$. Yield, $95 \%$. The white solid was washed with $\mathrm{CHCl}_{3}$ and $n$-pentane and dried in vacuo.

The $\mathrm{NBu}_{4}\left[\mathrm{PdCl}_{2}\right.$ (DMDT)] salt was prepared by reaction of $[\mathrm{PdCl}(\mathrm{DMDT})]_{n}(0.5 \mathrm{mmol})$ with $\mathrm{NBu}_{4} \mathrm{Cl}(0.55 \mathrm{mmol})$ in $\mathrm{CH}_{2} \mathrm{Cl}_{2}$ $\left(5 \mathrm{~cm}^{3}\right)$. An orange solution formed initially, which, on standing $(8 \mathrm{~h})$, separated an orange solid. The compound was filtered, washed with $\mathrm{CH}_{2} \mathrm{Cl}_{2}$ and dried under reduced pressure. Yield, $88 \%$. The $\mathrm{NBu}_{4}\left[\mathrm{PdCl}_{2}(\mathrm{PyDT})\right]$ complex synthesis was reported previously in Ref. [38].

\subsection{Synthesis of the en complexes}

The $[\mathrm{Pd}(\mathrm{PyDT})($ en $)] \mathrm{Cl}$ complex was prepared by reaction of $[\mathrm{PdCl}(\mathrm{PyDT})]_{n}(0.8 \mathrm{mmol})$ and en $(0.93 \mathrm{mmol})$ in $\mathrm{CHCl}_{3}\left(8 \mathrm{~cm}^{3}\right)$ with vigorous stirring $(24 \mathrm{~h})$. The pink suspension turned into a pale yellow solid, which was filtered, washed with $\mathrm{CHCl}_{3}$ and $n$-pentane and dried under reduced pressure. Yield, $83 \%$. The $[\mathrm{Pd}(\mathrm{ESDT})(\mathrm{en})] \mathrm{Cl}$ and $[\mathrm{Pd}(\mathrm{DMDT})(\mathrm{en})] \mathrm{Cl}$ analogues were prepared by reaction of the appropriate $[\mathrm{PdCl}(\text { dithiocarbamate })]_{n}$ intermediate with en, as reported in Refs. [28,40]. The $[\mathrm{Pd}(\mathrm{DMDT})(\mathrm{en})]\left[\mathrm{PdCl}_{2}\right.$ (DMDT)] complex was obtained by reaction of $[\mathrm{PdCl}(\mathrm{DMDT})]_{n}(1.1 \mathrm{mmol})$ with en $(0.55 \mathrm{mmol})$ in $\mathrm{CHCl}_{3}$ $\left(5 \mathrm{~cm}^{3} ; 2\right.$ days with vigorous stirring). The beige solid was separated by centrifugation, washed with $\mathrm{CHCl}_{3}$ and $n$-pentane and dried under reduced pressure. Yield, $72 \%$. By operating in the same conditions, the reaction of $[\mathrm{PdCl}(\mathrm{PyDT})]_{n}$ with en at molar ratio 1:0.5 yielded a mixture of $[\mathrm{Pd}(\mathrm{PyDT})(\mathrm{en})]\left[\mathrm{PdCl}_{2}\right.$ (PyDT)], $\left[\mathrm{Pd}(\mathrm{PyDT})_{2}\right]$ and $\left[\mathrm{PdCl}_{2}(\mathrm{en})\right]$. Physical data, elemental analyses, IR and NMR data of the products are collected in Tables 1, 2 and 3 , respectively. 


\subsection{Synthesis of the dap complexes}

The $[\mathrm{Pd}(\mathrm{PyDT})(\mathrm{dap})] \mathrm{Cl}$ complex separated as a pale yellow powder by reaction of $[\mathrm{PdCl}(\mathrm{PyDT})]_{n}(0.95 \mathrm{mmol})$ with equimolar dap in $\mathrm{CHCl}_{3}\left(8 \mathrm{~cm}^{3} ; 1\right.$ day with stirring). The solid was centrifugated and dried in vacuo. Yield, $80 \%$. The [Pd(DMDT)(dap)]Cl [40] and $[\mathrm{Pd}(\mathrm{ESDT})(\mathrm{dap})] \mathrm{Cl}$ samples were prepared following the same method. Particular attention should be paid to the reaction time, especially for the $[\mathrm{PdCl}(\mathrm{ESDT})]_{n} /$ dap system. If $[\mathrm{PdCl}(\mathrm{ESDT})]_{n}$ and dap (molar ratio $1: 1 ; 0.45 \mathrm{mmol}$ in $8 \mathrm{~cm}^{3}$ of $\mathrm{CHCl}_{3}$ ) are allowed to react for 5 days, the solid obtained is mainly $\left[\mathrm{Pd}(\mathrm{dap})_{2}\right] \mathrm{Cl}_{2}$, impure for $\left[\mathrm{Pd}(\mathrm{ESDT})_{2}\right]$, which is isolated by evaporating to dryness the mother solution. The reaction of $[\mathrm{PdCl} \text { (dithiocarbamate) }]_{n}$ samples with dap in $\mathrm{CHCl}_{3}$ at molar ratio 1:0.5 yielded always a mixture of $\left[\mathrm{PdCl}_{2}(\mathrm{dap})\right]$ and $\left[\mathrm{Pd}(\text { dithiocarbamate })_{2}\right]$. For example, the yellow powder obtained by reaction of $[\mathrm{PdCl}(\mathrm{PyDT})]_{n}(0.34 \mathrm{mmol})$ with dap in $\mathrm{CHCl}_{3}\left(0.18 \mathrm{mmol}\right.$ in $6 \mathrm{~cm}^{3} ; 2$ days with stirring) is a mixture of [Pd(PyDT) $)_{2}$ (IR: 1511s, 346s, 334s) and [ $\mathrm{PdCl}_{2}$ (dap)] (IR: 3243, 3204, 3121, 1595, 319w, 297s), both insoluble in chloroform. The exchange is particularly evident for the $[\mathrm{PdCl}(\mathrm{ESDT})]_{n} /$ dap system (molar ratio 1:0.5), the solid reaction product being essentially $\left[\mathrm{PdCl}_{2}\right.$ (dap)]. Elemental analyses, IR and NMR data of the products are collected in Tables 1, 2 and 3, respectively.

\subsection{Synthesis of the dab and dah complexes}

The binuclear complex $\left[\mathrm{Pd}_{2} \mathrm{Cl}_{2}(\mathrm{PyDT})_{2}(\mathrm{dab})\right]$ has been prepared by reaction of $[\mathrm{PdCl}(\mathrm{PyDT})]_{n}(0.82 \mathrm{mmol})$ with dab $(0.41 \mathrm{mmol})$ in $\mathrm{CHCl}_{3}\left(10 \mathrm{~cm}^{3}\right)$. A pale yellow solid is formed within few minutes, which is left on standing and then filtered, washed with $\mathrm{CHCl}_{3}$ and n-pentane and dried in vacuo. Yield, $90 \%$. The $\left[\mathrm{Pd}_{2} \mathrm{Cl}_{2}(\mathrm{PyDT})_{2}(\mathrm{dah})\right]$ complex was obtained in good yield (93\%) by reaction of $[\mathrm{PdCl}(\mathrm{PyDT})]_{n}$ and dah (molar ratio 1:0.5) in chloroform, whereas the synthesis of the $\left[\mathrm{Pd}_{2} \mathrm{Cl}_{2}(\mathrm{ESDT})_{2}\right.$ (diamine)] analogues (diamine $=$ dab or dah) was carried out in benzene $/ \mathrm{CH}_{2} \mathrm{Cl}_{2}$. For example, $[\mathrm{PdCl}(\mathrm{ESDT})]_{n}(0.6 \mathrm{mmol})$ and dah $(0.3 \mathrm{mmol})$ were allowed to react in benzene $/ \mathrm{CH}_{2} \mathrm{Cl}_{2}\left(5: 1 \mathrm{vol} / \mathrm{vol} ; 8 \mathrm{~cm}^{3} ; 3\right.$ days with stirring). The yellow solid was filtered, washed with benzene and $n$-pentane and dried in vacuo. Yield, $80 \%$. If the solvent was $\mathrm{CHCl}_{3}$, the yield was lower and the sample contained unidentified side products.

The reaction of $[\mathrm{PdCl}(\mathrm{PyDT})]_{n}$ with dab (or dah) in $\mathrm{CHCl}_{3}$ at molar ratio $1: 1$ yielded ionic species of formula $[\mathrm{Pd}(\mathrm{PyDT})(\mathrm{diami}-$ ne) $]_{n} \mathrm{Cl}_{n}$, which contained variable amounts of $\mathrm{CHCl}_{3}$ (from 0.3 to 1.0 for each polymer unit). For example, the [Pd(PyDT) (dah) $]_{n} \mathrm{Cl}_{n} \cdot n \mathrm{CHCl}_{3}$ complex was prepared by reaction of $[\mathrm{PdCl}(\mathrm{PyDT})]_{n}(0.78 \mathrm{mmol})$ and dah $(0.78 \mathrm{mmol})$ in $\mathrm{CHCl}_{3}\left(8 \mathrm{~cm}^{3}\right)$. The golden yellow solution separated on standing (1 day) yellow crystals of the product, which were filtered, washed with $\mathrm{CHCl}_{3}$ and dried in vacuo. Yield, 75\% and 73\% for dah and dab adducts, respectively. The chloroform amount in the samples was estimated by thermogravimetry. At contrary, chloroform was absent in samples of $[\mathrm{Pd}(\mathrm{ESDT})(\mathrm{dab})]_{n} \mathrm{Cl}_{n}$, which were obtained by reaction of equimolar $[\mathrm{PdCl}(\mathrm{ESDT})]_{n}$ and dab (molar ratio $1: 1$ ) in $\mathrm{CHCl}_{3}$ (1 day with stirring). Yield, 70\%. Elemental analyses, IR and NMR data of the products are collected in Tables 1, 2 and 3, respectively. $[\mathrm{Pd}(\mathrm{PyDT})(\mathrm{dah})]_{n} \mathrm{Cl}_{n}$ and $[\mathrm{Pd}(\mathrm{PyDT})(\mathrm{dab})]_{n} \mathrm{Cl}_{n}$ have been obtained without $\mathrm{CHCl}_{3}$ heating the samples under vacuum as suggested by thermograms, in order to obtain compounds suitable for biologic investigation.

\subsection{Experiments with human tumour cells}

Dithiocarbamate complexes were dissolved in dimethyl sulfoxide just before the experiments; calculated amounts of drug solution were added to the growth medium containing cells to a final solvent concentration of $0.5 \%$ which had no discernible effect on cell killing. Cisplatin was dissolved in $0.9 \% \mathrm{NaCl}$ solution.

MTT (3-(4,5-dimethylthiazol-2-yl)-2,5-diphenyltetrazolium bromide) and cisplatin were obtained from Sigma Chemical Co. St. Louis, USA.

\subsubsection{Cell cultures}

2008 human ovarian cancer cell line and its cisplatin resistant variant, $\mathrm{C}_{13} *$ cells, were kindly provided by Prof. G. Marverti (Department of Biomedical Science of Modena University, Italy) and A431 human cervix carcinoma were kindly provided by Prof. Zunino (Division of Experimental Oncology B, Istituto Nazionale dei Tumori, Milan, Italy). All cell lines were maintained in the logarithmic phase at $37{ }^{\circ} \mathrm{C}$ in a $5 \%$ carbon dioxide atmosphere using RPMI-1640 medium (Sigma Chemical Co.) containing 10\% foetal bovine serum (Euroclone, Milano, Italy) and supplemented with L-glutamine and with antibiotics (penicillin $50 \mathrm{U} \mathrm{mL}^{-1}$ and streptomycin $50 \mu \mathrm{g} \mathrm{mL}^{-1}$ ).

\subsubsection{Cytotoxicity assay}

The growth inhibitory effect towards tumour cell lines was evaluated by means of MTT (tetrazolium salt reduction) assay [41]. Briefly, between 3 and $5 \times 10^{-3}$ cells, dependent upon the growth characteristics of the cell line, were seeded in 96-well microplates in growth medium $(100 \mu \mathrm{L})$ and then incubated at $37{ }^{\circ} \mathrm{C}$ in a $5 \%$ carbon dioxide atmosphere. After $24 \mathrm{~h}$, the medium was removed and replaced with a fresh one containing the compound to be studied at the appropriate concentrations. Quadruplicate cultures were established for each treatment. Forty-eight hours later, each well was treated with $10 \mu \mathrm{L}$ of a $5 \mathrm{mg} \mathrm{mL}^{-1}$ MTT (3-(4,5-dimethylthiazol-2-yl)-2,5-diphenyltetrazolium bromide)

Table 1

Analytical ${ }^{\mathrm{a}}$ and physical data for the complexes.

\begin{tabular}{|c|c|c|c|c|c|c|c|}
\hline Compound & Formula & Colour & $\mathrm{C}$ & $\mathrm{H}$ & $\mathrm{N}$ & $v(\mathrm{CN})\left(\mathrm{cm}^{-1}\right)$ & Yield (\%) \\
\hline$[\mathrm{Pd}(\mathrm{PyDT})(\mathrm{en})] \mathrm{Cl}$ & $\mathrm{C}_{7} \mathrm{H}_{16} \mathrm{ClN}_{3} \mathrm{PdS}_{2}$ & pale yellow & $24.3(24.1)$ & $4.6(4.7)$ & $12.0(12.1)$ & 1526 & 83 \\
\hline$[\mathrm{Pd}(\mathrm{PyDT})(\mathrm{dap})] \mathrm{Cl}$ & $\mathrm{C}_{8} \mathrm{H}_{18} \mathrm{ClN}_{3} \mathrm{PdS}_{2}$ & pale yellow & $26.3(26.5)$ & $5.0(5.0)$ & $11.3(11.6)$ & 1520 & 80 \\
\hline$\left[\mathrm{Pd}_{2} \mathrm{Cl}_{2}(\mathrm{PyDT})_{2}(\mathrm{dab})\right]$ & $\mathrm{C}_{14} \mathrm{H}_{28} \mathrm{Cl}_{2} \mathrm{~N}_{4} \mathrm{Pd}_{2} \mathrm{~S}_{4}$ & nutmeg & $25.1(25.3)$ & $4.1(4.2)$ & $8.6(8.4)$ & 1544 & 90 \\
\hline$[\mathrm{Pd}(\mathrm{PyDT})(\mathrm{dab})]_{n} \mathrm{Cl}_{n} \cdot 1 / 3 \mathrm{CHCl}_{3}$ & $\mathrm{C}_{9.33} \mathrm{H}_{20.33} \mathrm{Cl}_{2} \mathrm{~N}_{3} \mathrm{PdS}_{2}$ & pale yellow & $26.7(26.9)$ & $4.4(4.9)$ & $9.7(10.0)$ & 1541 & 73 \\
\hline$\left[\mathrm{Pd}_{2} \mathrm{Cl}_{2}(\mathrm{PyDT})_{2}(\mathrm{dah})\right]$ & $\mathrm{C}_{17} \mathrm{H}_{34} \mathrm{Cl}_{2} \mathrm{~N}_{4} \mathrm{Pd}_{2} \mathrm{~S}_{4}$ & beige & $28.6(28.9)$ & $4.9(4.8)$ & $7.9(7.9)$ & 1534 & 93 \\
\hline$[\mathrm{Pd}(\mathrm{PyDT})(\mathrm{dah})]_{n} \mathrm{Cl}_{n} \cdot \mathrm{CHCl}_{3}$ & $\mathrm{C}_{13} \mathrm{H}_{27} \mathrm{Cl}_{4} \mathrm{~N}_{3} \mathrm{PdS}_{2}$ & yellow & $29.4(29.0)$ & $5.3(5.1)$ & $7.8(7.8)$ & 1534 & 75 \\
\hline$[\mathrm{Pd}(\mathrm{DMDT})(\mathrm{en})]\left[\mathrm{PdCl}_{2}(\mathrm{DMDT})\right]$ & $\mathrm{C}_{8} \mathrm{H}_{20} \mathrm{Cl}_{2} \mathrm{~N}_{4} \mathrm{Pd}_{2} \mathrm{~S}_{4}$ & beige & $16.9(16.4)$ & $3.1(3.4)$ & $9.2(9.6)$ & 1569 & 72 \\
\hline $\mathrm{NBu}_{4}\left[\mathrm{PdCl}_{2}(\mathrm{DMDT})\right]$ & $\mathrm{C}_{19} \mathrm{H}_{42} \mathrm{Cl}_{2} \mathrm{~N}_{2} \mathrm{PdS}_{2}$ & orange & $42.4(42.3)$ & $7.6(7.8)$ & $5.0(5.2)$ & 1563 & 88 \\
\hline$\left[\mathrm{Pd}_{2} \mathrm{Cl}_{2}(\mathrm{ESDT})_{2}(\mathrm{dab})\right]$ & $\mathrm{C}_{16} \mathrm{H}_{32} \mathrm{Cl}_{2} \mathrm{~N}_{4} \mathrm{O}_{4} \mathrm{Pd}_{2} \mathrm{~S}_{4}$ & yellow & $25.2(25.4)$ & $4.3(4.3)$ & $7.2(7.4)$ & 1536 & 80 \\
\hline$[\mathrm{Pd}(\mathrm{ESDT})(\mathrm{dab})]_{n} \mathrm{Cl}_{n}$ & $\mathrm{C}_{10} \mathrm{H}_{22} \mathrm{ClN}_{3} \mathrm{O}_{2} \mathrm{PdS}_{2}$ & pale yellow & $28.3(28.4)$ & $4.5(5.2)$ & $9.3(9.3)$ & 1525 & 70 \\
\hline$\left[\mathrm{Pd}_{2} \mathrm{Cl}_{2}(\mathrm{ESDT})_{2}(\mathrm{dah})\right]$ & $\mathrm{C}_{19} \mathrm{H}_{38} \mathrm{Cl}_{2} \mathrm{~N}_{4} \mathrm{O}_{4} \mathrm{Pd}_{2} \mathrm{~S}_{4}$ & yellow & $29.1(28.6)$ & $4.7(4.8)$ & $6.9(7.0)$ & 1521 & 75 \\
\hline$\left[\mathrm{PdCl}_{2}\right.$ (dap)] & $\mathrm{C}_{3} \mathrm{H}_{10} \mathrm{Cl}_{2} \mathrm{~N}_{4} \mathrm{Pd}$ & beige & $14.4(14.3)$ & $4.1(4.0)$ & $11.0(11.1)$ & & 61 \\
\hline$\left[\mathrm{Pd}(\text { dap })_{2}\right] \mathrm{Cl}_{2}$ & $\mathrm{C}_{6} \mathrm{H}_{20} \mathrm{Cl}_{2} \mathrm{~N}_{4} \mathrm{Pd}$ & white & $22.6(22.1)$ & $6.2(6.2)$ & $17.5(17.2)$ & & 95 \\
\hline
\end{tabular}

a Calculated values (\%) in parentheses. 
Table 2

Selected IR frequencies $\left(\mathrm{cm}^{-1}\right)^{\mathrm{a}}$ for the complexes.

\begin{tabular}{|c|c|c|c|c|c|c|c|c|c|c|c|}
\hline \multirow{4}{*}{$\begin{array}{l}\text { Compound } \\
{[\mathrm{Pd}(\text { PyDT })(\text { dap })] C l} \\
{[\mathrm{Pd}(\text { PyDT })(\text { en })] C l} \\
{[\mathrm{Pd}(\text { DMDT })(\text { en })]\left[\mathrm{PdCl}_{2}(\text { DMDT })\right]}\end{array}$} & \multicolumn{3}{|l|}{$v(\mathrm{NH})$} & \multicolumn{3}{|l|}{$\delta\left(\mathrm{NH}_{2}\right)$} & \multicolumn{5}{|c|}{ Far IR $\left(400-200 \mathrm{~cm}^{-1}\right)$} \\
\hline & $3255 \mathrm{~m}$ & 3169w, & $3049 \mathrm{sbr}$ & $1598 v w$ & $359 s$ & $335 w$ & $322 w$ & & & $254 w$ & $226 w$ \\
\hline & $3276 \mathrm{~m}$ & $3176 w$ & $3056 \mathrm{sbr}$ & $1595 w, 1548 w$ & $364 s$ & $333 w$ & $322 w$ & & $279 w$ & $230 \mathrm{mbr}$ & \\
\hline & 3290w, & $3246 \mathrm{~m}, 3208 \mathrm{~m}$ & $3145 w$ & $1570 v w$ & $359 w$ & $348 m$ & & $304 \mathrm{~m}$ & $272 \mathrm{~m}$ & & \\
\hline $\mathrm{NBu}_{4}\left[\mathrm{PdCl}_{2}(\mathrm{DMDT})\right]$ & & & & & $350 w$ & & & $\underline{301 \mathrm{~m}}$ & $279 \mathrm{~m}$ & & $226 \mathrm{~m}$ \\
\hline$\left[\mathrm{Pd}_{2} \mathrm{Cl}_{2}(\mathrm{PyDT})_{2}(\mathrm{dab})\right]$ & $3267 \mathrm{~m}$ & $3218 w$ & 3148w & $1584 \mathrm{vw}$ & $366 m$ & $336 w$ & & $293 \mathrm{~m}$ & & $258 \mathrm{mbr}$ & \\
\hline$\left[\mathrm{Pd}_{2} \mathrm{Cl}_{2}(\mathrm{PyDT})_{2}(\mathrm{dah})\right]$ & $3274 \mathrm{~m}$ & $3232 \mathrm{~m}$ & $3155 w$ & $1581 w$ & $364 m$ & $340 \mathrm{~m}$ & & $297 \mathrm{~m}$ & & $237 w b r$ & $224 \mathrm{wbr}$ \\
\hline$[\mathrm{Pd}(\mathrm{PyDT})(\mathrm{dab})]_{n} \mathrm{Cl}_{n} \cdot 1 / 3 \mathrm{CHCl}_{3}{ }^{\mathrm{b}}$ & $3246 w$ & $3126 \mathrm{mbr}$ & $3070 w$ & $1584 w$ & $365 \mathrm{~m}$ & $336 w$ & & & & $268 \mathrm{~ms}$ & $232 \mathrm{mbr}$ \\
\hline$[\mathrm{Pd}(\mathrm{PyDT})(\mathrm{dah})]_{n} \mathrm{Cl}_{n} \cdot \mathrm{CHCl}_{3}{ }^{\mathrm{b}}$ & $3210 w$ & $3162 w$ & $3098 \mathrm{mbr}$ & 1598w, 1578w & $359 m$ & $335 w$ & & & & & \\
\hline$\left[\mathrm{Pd}_{2} \mathrm{Cl}_{2}(\mathrm{ESDT})_{2}(\mathrm{dab})\right]$ & $3309 \mathrm{~m}$ & $3232 \mathrm{~m}$ & $3155 w$ & $1591 w$ & $380 \mathrm{~m}$ & $350 w$ & $324 w$ & $291 \mathrm{~m}$ & & & \\
\hline$[\mathrm{Pd}(\mathrm{ESDT})(\mathrm{dab})]_{n} \mathrm{Cl}_{n}$ & 3204sh, & $3151 \mathrm{mbr}$, & $3080 \mathrm{mbr}$ & $1596 w, 1567 w$ & $379 m$ & $352 w$ & $319 w$ & & $284 w$ & $258 w$ & \\
\hline$\left[\mathrm{Pd}_{2} \mathrm{Cl}_{2}(\mathrm{ESDT})_{2}(\mathrm{dah})\right]$ & $3281 \mathrm{~m}$ & $3224 \mathrm{~m}$ & $3150 w$ & $1567 w$ & $381 \mathrm{~m}$ & $352 w$ & $324 w$ & $293 m$ & & & $240 w$ \\
\hline$\left[\mathrm{PdCl}_{2}\right.$ (dap)] & $3243 \mathrm{~m}$ & $3204 w$ & $3121 \mathrm{w}$ & $1595 \mathrm{vw}, 1563 \mathrm{~m}$ & $365 \mathrm{~m}$ & 329sh & & $\overline{319 m}$ & $297 s$ & & $248 \mathrm{mbr}$ \\
\hline$\left[\mathrm{Pd}(\text { dap })_{2}\right] \mathrm{Cl}_{2}$ & & $3140 \mathrm{mbr}$ & $3060 \mathrm{mbr}$ & 1598w & $365 w$ & $346 w$ & & & & & $249 \mathrm{mbr}$ \\
\hline
\end{tabular}

a $v(\mathrm{Pd}-\mathrm{Cl})$ underlined.

b $\mathrm{CHCl}_{3}, 751 \mathrm{~cm}^{-1}$

Table 3

${ }^{1} \mathrm{H}$ NMR data for the complexes in DMSO- $d_{6}\left(\mathrm{ppm}, T=25^{\circ} \mathrm{C}\right)$.

\begin{tabular}{|c|c|c|c|c|c|}
\hline Compound & $\mathrm{NH}_{2}$ & $\alpha \mathrm{CH}_{2}$ & $\beta \mathrm{CH}_{2}$ & $\gamma, \delta \mathrm{CH}_{2}$ & dithiocarbamate \\
\hline$[\mathrm{PdCl}(\operatorname{PyDT})]_{n}$ & & & & & PyDT: $\left(\mathrm{CH}_{2}\right)_{2} \mathrm{~N}$ 3.66; $\left(\mathrm{CH}_{2}\right)_{2} 1.97$ \\
\hline$[\mathrm{Pd}(\mathrm{PyDT})(\mathrm{en})] \mathrm{Cl}$ & $5.06 \mathrm{w}, 4.88$ & 2.54 & & & PyDT: $\left(\mathrm{CH}_{2}\right)_{2} \mathrm{~N} 3.59 ;\left(\mathrm{CH}_{2}\right)_{2} 1.95$ \\
\hline$[\mathrm{Pd}(\operatorname{PyDT})($ dap $)] \mathrm{Cl}$ & $4.54 w, 4.37$ & 2.55 & 1.63 & & PyDT: $\left(\mathrm{CH}_{2}\right)_{2} \mathrm{~N} 3.59 ;\left(\mathrm{CH}_{2}\right)_{2} 1.95$ \\
\hline $\mathrm{NBu}_{4}\left[\mathrm{PdCl}_{2}(\mathrm{DMDT})\right]^{\mathrm{a}}$ & & & & & DMDT: $\left(\mathrm{CH}_{3}\right)_{2} \mathrm{~N} 3.23$ \\
\hline$[\mathrm{Pd}(\mathrm{DMDT})(\mathrm{en})]\left[\mathrm{PdCl}_{2}(\mathrm{DMDT})\right]$ & 4.90 & 2.52 & & & DMDT: $\left(\mathrm{CH}_{3}\right)_{2} \mathrm{~N} 3.22$ \\
\hline$\left[\mathrm{Pd}_{2} \mathrm{Cl}_{2}(\mathrm{PyDT})_{2}(\mathrm{dab})\right]$ & 4.42 & $2.64^{\mathrm{b}}$ & $1.94^{\mathrm{c}}$ & & PyDT: $\left(\mathrm{CH}_{2}\right)_{2} \mathrm{~N} 3.60 ;\left(\mathrm{CH}_{2}\right)_{2} 1.94^{\mathrm{c}}$ \\
\hline$\left[\mathrm{Pd}_{2} \mathrm{Cl}_{2}(\mathrm{ESDT})_{2}(\mathrm{dab})\right]$ & 4.54 & $2.63^{\mathrm{b}}$ & 1.94 & & ESDT: OEt $1.21,4.18 ; \mathrm{NCH}_{3} 3.22 ; \mathrm{NCH}_{2} 4.60$ \\
\hline$[\mathrm{Pd}(\mathrm{PyDT})(\mathrm{dab})]_{n} \mathrm{Cl}_{n} \cdot 1 / 3 \mathrm{CHCl}_{3}{ }^{\mathrm{d}}$ & 4.40 & 2.64 & $1.95^{\mathrm{c}}$ & & PyDT: $\left(\mathrm{CH}_{2}\right)_{2} \mathrm{~N} 3.60 ;\left(\mathrm{CH}_{2}\right)_{2} 1.95^{\mathrm{c}}$ \\
\hline$[\mathrm{Pd}(\mathrm{ESDT})(\mathrm{dab})]_{n} \mathrm{Cl}_{n}$ & 4.58 & 2.63 & 1.95 & & ESDT: OEt $1.21,4.16 ; \mathrm{N}\left(\mathrm{CH}_{3}\right) 3.23 ; \mathrm{N}\left(\mathrm{CH}_{2}\right) 4.54 \mathrm{w}, 4.57 \mathrm{~s}$ \\
\hline$\left[\mathrm{Pd}_{2} \mathrm{Cl}_{2}(\mathrm{PyDT})_{2}(\mathrm{dah})\right]$ & $4.31,4.11$ & 2.38 & $1.73 w, 1.59$ & $1.33 \mathrm{w}, 1.23$ & PyDT: $\left(\mathrm{CH}_{2}\right)_{2} \mathrm{~N} 3.58 ;\left(\mathrm{CH}_{2}\right)_{2} 1.93$ \\
\hline$\left[\mathrm{Pd}_{2} \mathrm{Cl}_{2}(\mathrm{ESDT})_{2}(\mathrm{dah})\right]$ & $4.57,4.59$ & 2.36 & 1.59 & 1.40 & ESDT: OEt $1.21,4.16 ; \mathrm{N}\left(\mathrm{CH}_{3}\right) 3.22 ; \mathrm{N}\left(\mathrm{CH}_{2}\right) 4.50,4.52$ \\
\hline$[\mathrm{Pd}(\mathrm{PyDT})(\mathrm{dah})]_{n} \mathrm{Cl}_{n} \cdot \mathrm{CHCl}_{3}{ }^{\mathrm{d}}$ & 4.36 & 2.40 & $1.73,1.60 \mathrm{w}$ & $1.24 \mathrm{w}$ & PyDT: $\left(\mathrm{CH}_{2}\right)_{2} \mathrm{~N} 3.61 ;\left(\mathrm{CH}_{2}\right)_{2} 1.95$ \\
\hline
\end{tabular}

a In $\mathrm{CDCl}_{3}$.

b Weak signals at $2.4 \mathrm{ppm}$ are also present.

c The amine $\beta \mathrm{CH}_{2}$ resonance superimposes to the PyDT ring $\mathrm{CH}_{2}$ signal.

${ }^{d} \mathrm{CHCl}_{3}$ proton resonance at $8.31 \mathrm{ppm}$.

saline solution, and after $5 \mathrm{~h}$ of incubation, $100 \mu \mathrm{L}$ of a sodium dodecyl sulfate (SDS) solution in $\mathrm{HCl} 0.01 \mathrm{M}$ were added. After overnight incubation, the inhibition of cell growth induced by the tested complexes was detected by measuring the absorbance of each well at $540 \mathrm{~nm}$ using a Bio-Rad microplate reader. Mean absorbance for each drug dose was expressed as a percentage of the control untreated well absorbance and plotted versus drug concentration. $\mathrm{IC}_{50}$ values represent the drug concentrations that reduced the mean absorbance at $540 \mathrm{~nm}$ to $50 \%$ of those in the untreated control wells.

\section{Results and discussion}

By reaction of the $[\mathrm{PdCl}(\text { dithiocarbamate })]_{n}$ precursors with the appropriate diamine either ionic or neutral species can be isolated (Chart 2).

The $[\mathrm{PdCl} \text { (dithiocarbamate) }]_{n}$ intermediates are probably dimers through chlorine bridges, as observed for di- $\mu$-chlorobis[di- $n$-butyldithiocarbamate]dipalladium [42]. Nevertheless, the presence of polymeric species containing more than two units cannot be excluded. In the $[\mathrm{PdCl} \text { (mercaptonicotinic acid) }]_{3}$ species the single $\mathrm{PdCl}$ (mercaptonicotinic) units, in which the anion is $\mathrm{S}, \mathrm{N}$ chelated to the metal, form a trimeric molecule held by sulfur bridges, the chlorine atoms being terminal [43]. An unique and exotic pentanuclear $\mathrm{Pt}_{5}$ structure has been recently reported by the author where $\mathrm{S}$ atoms of PyDT ligands act as chelating and bridging donors at the same time [44].

$$
\begin{aligned}
& (\overbrace{\mathrm{S}}^{\mathrm{S}_{\mathrm{Pd}}} \searrow_{\mathrm{NH}_{2}}^{\mathrm{NH}_{2}} \overbrace{\left(\mathrm{CH}_{2}\right)_{\mathrm{n}}}^{\oplus} \mathrm{Cl} \\
& \begin{array}{l}
\mathrm{n}=2 \text { (en); } 3 \text { (dap) } \\
\mathrm{Pd} / \mathrm{en} \text { or dap 1:1 }
\end{array}
\end{aligned}
$$<smiles></smiles>

$\mathrm{n}=4$ (dab); 7 (dah) Pd/en or dap 1:1

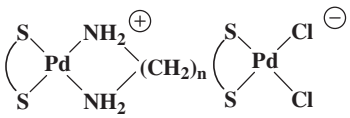

$$
\begin{aligned}
& \mathrm{n}=2 \text { (en); } 3 \text { (dap) }
\end{aligned}
$$<smiles>ClC1(NCCNCCN[Te]2(Cl)SCS2)SCS1</smiles>

$\mathrm{n}=4$ (dab); 7 (dah) Pd/en or dap 1:0.5

Chart 2.

The $[\mathrm{PdCl}(\text { dithiocarbamate })]_{n}$ intermediates have been prepared by thermal decomposition of the parent dithioester complexes at the appropriate temperature as reported in Section 2. The trend of the $[\mathrm{PdCl}(\text { dithiocarbamate })]_{n}$ complex reaction with diamines depends on either stoichiometric ratio or diamine chain length. When $[\mathrm{PdCl}(\mathrm{PyDT})]_{n}$ is reacted with ethylenediamine (en) or 1,3-diaminopropane (dap) in chloroform at molar ratio $1: 1$, the ionic $[\mathrm{Pd}(\mathrm{PyDT})(\mathrm{en})] \mathrm{Cl}$ and $[\mathrm{Pd}(\mathrm{PyDT})(\mathrm{dap})] \mathrm{Cl}$ species are obtained (Chart 2, Table 1), as for the ESDT and DMDT analogues $[28,40]$. Sample purity depends on reaction time. For example, if $[\mathrm{PdCl}(\mathrm{ESDT})]_{n}$ and dap (molar ratio 1:1) are kept under stirring in chloroform for 5 days, the main reaction products are $\left[\mathrm{Pd}(\mathrm{ESDT})_{2}\right]$ 
and $\left[\mathrm{Pd}(\mathrm{dap})_{2}\right] \mathrm{Cl}_{2}$, supporting a rearrangement in the initial product, [Pd(ESDT)(dap)]Cl, to give the symmetrical bis-chelated species. The process can be followed by infrared spectra of samples drawn out at different reaction times. The exchange process is particularly evident when $[\mathrm{PdCl} \text { (dithiocarbamate) }]_{n}$ and dap are reacted at molar ratio 1:0.5. In this case a mixture of $[\mathrm{Pd}$ (dithiocarbamate $\left.)_{2}\right]$ and $\left[\mathrm{PdCl}_{2}\right.$ (dap)] is formed, the initial $\mathrm{N}$ attack to metal being followed by formation of the diamine chelate ring (Chart 3 ).

The infrared spectrum of the final reaction mixture contains essentially the bands of the components. In the $v(\mathrm{NH})$ region the spectrum shows three well resolved bands at 3243, 3204 and $3121 \mathrm{~cm}^{-1}$, the $\delta\left(\mathrm{NH}_{2}\right)$ absorption being observed at $1563 \mathrm{~cm}^{-1}$. In the $\mathrm{Pd}-\mathrm{Cl}$ region two strong absorptions are present (319 and $297 \mathrm{~cm}^{-1}$ ), which coincide with those of $\left[\mathrm{PdCl}_{2}(\mathrm{dap})\right]$. The $v(\mathrm{CN})$ band of PyDT is at $1511 \mathrm{~cm}^{-1}$, as for [Pd(PyDT) $)_{2}$ ] and at lower energy with respect to the corresponding value in $[\mathrm{PdCl}(\mathrm{PyDT})]_{n}$ $\left(1548 \mathrm{~cm}^{-1}\right)$ or [PdCl(PyDT)(DMSO)] $\left(1554 \mathrm{~cm}^{-1}\right)$ [38]. Moreover, the far infrared spectrum contains two strong bands at 345 and $334 \mathrm{~cm}^{-1}$, characteristic of $\left[\mathrm{Pd}(\mathrm{PyDT})_{2}\right][38]$. When $[\mathrm{PdCl}(\mathrm{PyDT})]_{n}$ and dap are reacted at molar ratio $1: 1$, the initial product is $[\operatorname{Pd}(\operatorname{PyDT})(\mathrm{dap})] \mathrm{Cl}$, whose spectrum shows three absorption in the $3300-3000 \mathrm{~cm}^{-1}$ region, the stronger one at $3049 \mathrm{~cm}^{-1}$ being characteristic of ionic species, as observed for the en analogues (Table 2). If the solid is kept in the mother solution for several days with stirring, the amount of the $\left[\mathrm{Pd}(\mathrm{PyDT})_{2}\right]$ and $\left[\mathrm{Pd}(\mathrm{dap})_{2}\right] \mathrm{Cl}_{2}$ species increases, as indicated by the $\left[\mathrm{Pd}(\mathrm{PyDT})_{2}\right]$ bands at 1511,345 and $334 \mathrm{~cm}^{-1}$. A similar behaviour is observed for the $\mathrm{PdCl}(\mathrm{DMDT}) /$ dap and $\mathrm{PdCl}(\mathrm{ESDT}) /$ dap systems in the same solvent (molar ratio $1: 0.5)$. In particular, being $\left[\mathrm{Pd}(\mathrm{ESDT})_{2}\right]$ slightly soluble in chloroform, the main product of the reaction of $[\mathrm{PdCl}(\mathrm{ESDT})]_{n}$ with dap is $\left[\mathrm{PdCl}_{2}\right.$ (dap)], containing small amounts of $\left[\mathrm{Pd}(\mathrm{ESDT})_{2}\right]$. The reaction of $[\mathrm{PdCl}(\mathrm{PyDT})]_{n}$ with ethylenediamine at molar ratio $1: 1$ yields the usual $[\mathrm{Pd}(\mathrm{PyDT})(\mathrm{en})] \mathrm{Cl}$ species, whereas at molar ratio 1:0.5 a mixture of $\left[\mathrm{Pd}(\mathrm{PyDT})_{2}\right]$ and $\left[\mathrm{PdCl}_{2}(\mathrm{en})\right]$ is obtained, as for 1,3-diaminopropane. In the same conditions the $\mathrm{PdCl}(\mathrm{DMDT}) / \mathrm{en}$ system forms probably the [Pd(DMDT)(en)][ $\mathrm{PdCl}_{2}$ (DMDT)] complex (Chart 3). In order to clarify the product nature we have synthesized the $\mathrm{NBu}_{4}\left[\mathrm{PdCl}_{2}\right.$ (DMDT)] salt, characterized by two $\mathrm{Pd}-\mathrm{Cl}$ absorptions at 301 and $279 \mathrm{~cm}^{-1}$, the $v(\mathrm{CN})$ band being at $1563 \mathrm{~cm}^{-1}$. Accordingly, the spectrum of the [Pd(DMDT)(en)] $\left[\mathrm{PdCl}_{2}(\mathrm{DMDT})\right]$ complex contains one $v(\mathrm{CN})$ absorption for both ionic moieties $\left(1569 \mathrm{~cm}^{-1}\right)$, the Pd-Cl bands at 304 and $272 \mathrm{~cm}^{-1}$ having the shape and relative intensities of those observed for the tetrabutylammonium salt.

As a general observation, ethylenediamine and 1,3-diaminopropane assume the stable chelate arrangement yielding ionic species of the type $[\mathrm{Pd}($ dithiocarbamate)(diamine $)] \mathrm{Cl}$, which can undergo

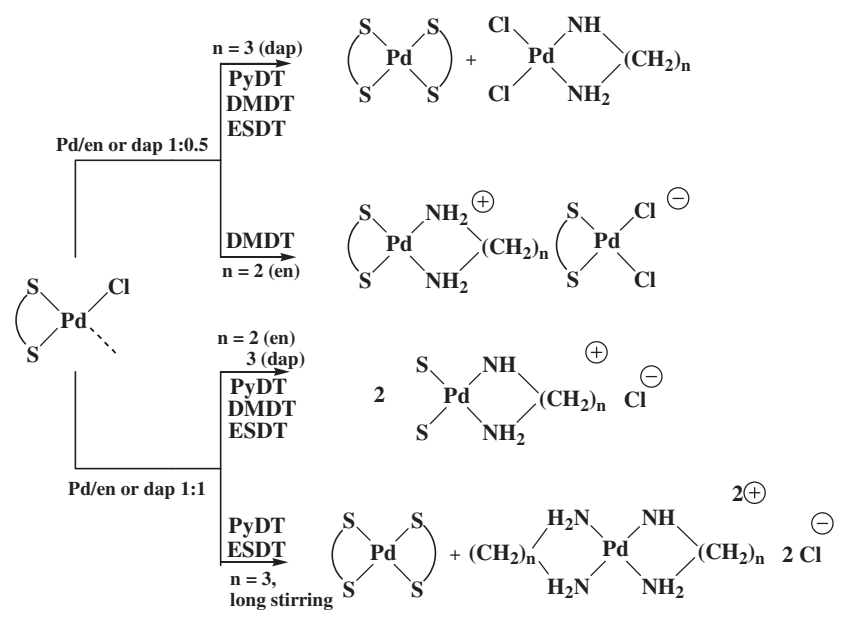

Chart 3. with time ligand rearrangement to form [ $\left.\mathrm{Pd}(\text { dithiocarbamate })_{2}\right]$ and $\left[\mathrm{Pd}(\text { diamine })_{2}\right] \mathrm{Cl}_{2}$. When the reaction is carried out at molar ratio $1: 0.5$, the reaction products are $\left[\mathrm{PdCl}_{2}\right.$ (amine) $]$ and the appropriate bis-dithiocarbamate (dithiocarbamate $=$ PyDT or ESDT), except for the $\mathrm{PdCl}(\mathrm{DMDT}) /$ en system, in which ethylenediamine chelation to the $\operatorname{Pd}(\mathrm{DMDT})^{+}$moiety causes the transfer of the chlorine ion to another $\mathrm{PdCl}(\mathrm{DMDT})$ unit yielding the [Pd(DMDT)(en)] $\left[\mathrm{PdCl}_{2}\right.$ (DMDT)] complex (Chart 3).

The reactions of $[\mathrm{PdCl}(\text { dithiocarbamate })]_{n}$ with diamines containing longer chains, as 1,4-diaminobutane (dab) and 1,7-diaminoheptane (dah), follow a totally different trend (Chart 2). When $[\mathrm{PdCl}(\mathrm{PyDT})]_{n}$ is allowed to react with either dab or dah at molar ratio 1:0.5, the binuclear complexes $\left[\mathrm{Pd}_{2} \mathrm{Cl}_{2}(\mathrm{PyDT})_{2}\right.$ (diamine)] are obtained, in which the diamine nitrogen atoms bind two different $\mathrm{PdCl}(\mathrm{PyDT})$ moieties. By operating at molar ratio $1: 1$, species of general formula $[\mathrm{Pd}(\mathrm{PyDT})(\text { diamine })]_{n} \mathrm{Cl}_{n} \cdot x \mathrm{CHCl}_{3}$ are obtained, in which each $\operatorname{Pd}(\mathrm{PyDT})^{+}$unit binds to the nitrogen atom of two different diamines, the whole arrangement leading to a polymeric structure of bridging diamines. The samples contain always variable amount of chloroform (from 0.3 to 1.0). As shown in Fig. 1 the thermogram of a $[\mathrm{Pd}(\mathrm{PyDT})(\mathrm{dah})]_{n} \mathrm{Cl}_{n} \cdot n \mathrm{CHCl}_{3}$ sample shows $\mathrm{CHCl}_{3}$ release in the $60-125^{\circ} \mathrm{C}$ temperature interval (DTA endotherm, $122^{\circ} \mathrm{C}$; weight loss of $21.5 \%$ against a calculated value of $22.2 \%$ ). The desolvated sample is stable up to $250{ }^{\circ} \mathrm{C}$, successive pyrolysis yielding palladium (total weight loss of $79.7 \%$ against calculated $80.2 \%$ ). The degradation process ends at ca. $500{ }^{\circ} \mathrm{C}$. The weight increase in the $500-800^{\circ} \mathrm{C}$ range is caused by oxygen uptake on the metal surface to form PdO, which decomposes to give palladium at $812^{\circ} \mathrm{C}$.

The IR spectra of the polynuclear species contain one $v(\mathrm{CN})$ band in the $1545-1530 \mathrm{~cm}^{-1}$ interval. The binuclear $\left[\mathrm{Pd}_{2} \mathrm{Cl}_{2}(\mathrm{PyDT})_{2}\right.$ (diamine) $]$ complexes contain one $\mathrm{Pd}-\mathrm{Cl}$ band at ca. $295 \mathrm{~cm}^{-1}$, which is absent in the polymeric [Pd(PyDT)(diamine) $]_{n} \mathrm{Cl}_{n}$ samples. The $\mathrm{PdCl}(\mathrm{ESDT}) /$ diamine (diamine $=$ dab or dah $)$ system gave analogous results, binuclear complexes like $\left[\mathrm{Pd}_{2} \mathrm{Cl}_{2}(\mathrm{ESDT})_{2}\right.$ (diamine)] or polymeric species as [Pd(ESDT)(diamine) $]_{n} \mathrm{Cl}_{n}$ being isolated. The IR spectra follow the trend observed for the PyDT analogues, the binuclear species showing one $\mathrm{Pd}-\mathrm{Cl}$ absorption at ca. $292 \mathrm{~cm}^{-1}$, which is absent in $[\operatorname{Pd}(\mathrm{ESDT})(\mathrm{dab})]_{n} \mathrm{Cl}_{n}$.

The proton NMR spectra of the complexes in deuterated dimethyl sulfoxide are reported in Table 3. In this solvent the $[\mathrm{PdCl}(\mathrm{PyDT})]_{n}$ complex shows two signals at 3.66 and $1.97 \mathrm{ppm}$, assigned to methylene groups bound to nitrogen and to ring methylene groups, respectively. Those resonances are nearly unchanged in the PyDT complexes, whereas the position of the $\mathrm{NH}_{2}$ signals supports diamine coordination in all the reported compounds. The spectra of the simple $\left[\mathrm{PdCl}_{2}\right.$ (dap)] and $\left[\mathrm{Pd}(\mathrm{dap})_{2}\right] \mathrm{Cl}_{2}$ species contain the $\mathrm{NH}_{2}$ proton signal of the chelated diamine at ca. $4.35 \mathrm{ppm}$, very close to the value observed for the related complexes of Table 3. In all compounds the $\mathrm{NH}_{2}$ proton signals fall in

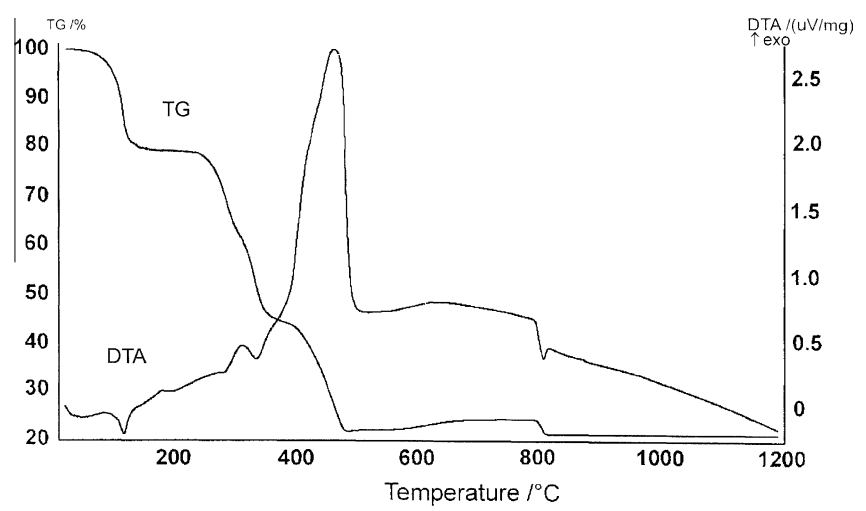

Fig. 1. Thermograms of $[\mathrm{Pd}(\mathrm{PyDT})(\mathrm{dah})]_{n} \mathrm{Cl}_{n} \cdot \mathrm{CHCl}_{3}$. 
the 4.3-5 ppm range, no evidence of free $\mathrm{NH}_{2}$ groups being observed. The mixed species [PdCl(ESDT) $($ amine $)]$ (amine $=n$-propylamine or cyclobutylamine) showed the $\mathrm{NH}_{2}$ signal of the monodentate ligand at ca. $4.2 \mathrm{ppm}$, whereas ligand release in $\left[\operatorname{Pd}(D M D T)(n \text {-propylamine })_{2}\right] C l$ solutions to form the parent [PdCl(DMDT)(n-propylamine)] species was clearly evident by the free $\mathrm{NH}_{2}$ signal at $1.5 \mathrm{ppm}$. The spectra have been registered immediately after sample dissolution. Aged solution (4 days) present weak side peaks for the diamine proton signals, particularly evident for the binuclear species, in which the diamines acts as monodentate toward each metal centre. A similar trend has been observed previously for [ $\mathrm{PdCl}$ (dithiocarbamate)(amine)] samples, the solvent interacting more easily with monodentate amines than for chelating diamines $[28,40]$.

The new palladium (II) complexes were preliminarily tested for their cytotoxic properties on two human cancer cell lines, 2008 and A431, from ovarian and cervix carcinoma, respectively. For comparison purpose, the cytotoxicity of cisplatin was evaluated under the same experimental conditions. $\mathrm{IC}_{50}$ values, calculated from the dose-survival curves obtained after $48 \mathrm{~h}$ drug treatment by MTT test, are shown in Table 4.

Both ionic $[\mathrm{Pd}($ dithiocarbamate)(diamine) $] \mathrm{Cl}$ (dithiocarbamate being PyDT; diamine being en or dap) and the dap complexes $\left[\mathrm{Pd}(\mathrm{dap}) \mathrm{Cl}_{2}\right]$ and $\left[\mathrm{Pd}(\mathrm{dap})_{2}\right] \mathrm{Cl}_{2}$ proved to be quite ineffective against 2008 and A431 tumour cell lines (Table 4). These results are in line with those previously reported for $[\mathrm{Pd}(\mathrm{ESDT})(\mathrm{en})] \mathrm{Cl}$, which showed a lower cytotoxicity than cisplatin toward HeLa cells $\left(\mathrm{IC}_{50}, 77.0\right.$ and $6.33 \mu \mathrm{M}$ for [Pd(ESDT)(en)]Cl and cisplatin, respectively) [28], as well as for [Pd(DMDT)(en)]Cl and the analogous dap derivative which have been found inactive toward KB cell line [40]. The total ineffectiveness showed by [Pd(PyD$\mathrm{T})($ en $)]\left[\mathrm{PdCl}_{2}\right.$ (PyDT) $]$ and $\mathrm{Bu}_{4} \mathrm{~N}\left[\mathrm{PdCl}_{2}\right.$ (DMDT)] derivatives, confirmed that ionic species containing chelating either diamine or dithiocarbamate were generally inactive, a certain activity being observed when the sulfur donor was ESDT [28].

Binuclear and polynuclear Pd derivatives elicited a cytotoxicity that was dependent on the nature of either dithiocarbamate type or diamine chain length. Among PyDT derivatives, dinuclear $\left[\mathrm{Pd}_{2} \mathrm{Cl}_{2}(\mathrm{PyDT})_{2}(\mathrm{dab})\right]$ was totally inactive whereas dinuclear $\left[\mathrm{Pd}_{2} \mathrm{Cl}_{2}(\mathrm{PyDT})_{2}(\mathrm{dah})\right]$ complex elicited a rather similar cell death induction over two cancer cells, with an average $\mathrm{IC}_{50}$ value of $56.52 \mu \mathrm{M}$.

ESDT Pd derivatives showed a significant in vitro antitumour activity which was dose-dependent against both tumour cell lines (Fig. 2A and B). In particular, despite $\left[\mathrm{Pd}_{2} \mathrm{Cl}_{2}(\mathrm{ESTD})_{2}(\mathrm{dab})\right]$ was less effective than cisplatin in inhibiting cancer cell growth, the ionic polynuclear $[\mathrm{Pd}(\mathrm{ESDT})(\mathrm{dab})]_{n} \mathrm{Cl}_{n}$ species and the neutral binuclear $\left[\mathrm{Pd}_{2} \mathrm{Cl}_{2}(\mathrm{ESDT})_{2}(\mathrm{dah})\right]$ complex displayed an antiproliferative po-

Table 4

Cytotoxic activity.

\begin{tabular}{lll}
\hline Compound & 2008 & A431 \\
\hline$\left[\mathrm{Pd}_{2} \mathrm{Cl}_{2}(\mathrm{PyDT})_{2}(\mathrm{dah})\right]$ & $52.91 \pm 3.32$ & $60.14 \pm 0.42$ \\
{$\left[\mathrm{Pd}_{2} \mathrm{Cl}_{2}(\mathrm{PyDT})_{2}(\mathrm{dab})\right]$} & $>100$ & $>100$ \\
{$\left[\mathrm{Pd}_{2} \mathrm{Cl}_{2}(\mathrm{ESDT})_{2}(\mathrm{dah})\right]$} & $16.36 \pm 1.14$ & $14.32 \pm 1.23$ \\
{$\left[\mathrm{Pd}_{2} \mathrm{Cl}_{2}(\mathrm{ESDT})_{2}(\mathrm{dab})\right]$} & $42.47 \pm 2.72$ & $36.55 \pm 2.86$ \\
{$[\mathrm{Pd}(\mathrm{ESDT})(\mathrm{dab})]_{n} \mathrm{Cl}_{n}$} & $18.40 \pm 1.81$ & $21.50 \pm 2.63$ \\
{$[\mathrm{Pd}(\mathrm{PyDT})($ en $)] C l$} & $>100$ & $>100$ \\
{$[\mathrm{Pd}(\mathrm{PyDT})($ dap $)] C l$} & $>100$ & $>100$ \\
{$[\mathrm{Pd}(\mathrm{PyDT})($ en $)]\left[\mathrm{PdCl} \mathrm{Pd}_{2}(\mathrm{PyDT})\right]$} & $>100$ & $>100$ \\
$\mathrm{Bu} \mathrm{N}\left[\mathrm{PdCl} l_{2}(\mathrm{DMDT})\right]$ & $>100$ & $>100$ \\
{$\left[\mathrm{Pd}(\right.$ dap $\left.) \mathrm{Cl}_{2}\right]$} & $>100$ & $>100$ \\
{$\left[\mathrm{Pd}(\text { dap })_{2}\right] C C_{2}$} & $>100$ & $>100$ \\
$\mathrm{Cisplatin}$ & $12.24 \pm 2.15$ & $19.53 \pm 1.75$ \\
\hline
\end{tabular}

$\mathrm{SD}=$ standard deviation. $\mathrm{IC}_{50}$ values were calculated by probit analysis $\left(P<0.05, \chi^{2}\right.$ test). Cells ( $3-5 \times 10^{4} \mathrm{ml}^{-1}$ ) were treated for $48 \mathrm{~h}$ with increasing concentrations of tested compounds. Cytotoxicity was assessed by MTT test.
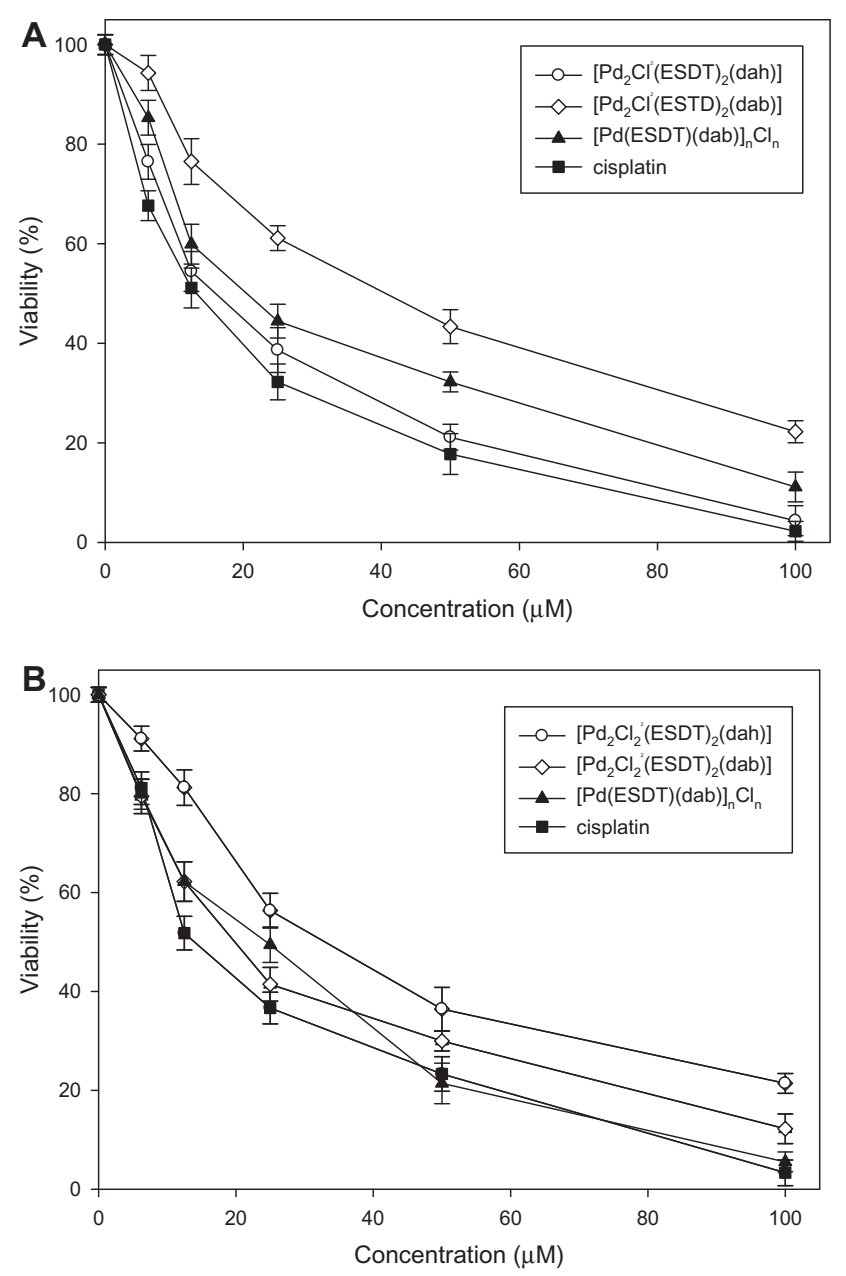

Fig. 2. Sensitivity of 2008 (A) and $A 431$ (B) cells to Pd complexes $\left[\mathrm{Pd}_{2} \mathrm{Cl}_{2}(\mathrm{ESDT})_{2}\right.$ -

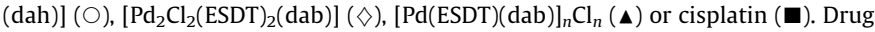
exposure with the indicated compounds was for $48 \mathrm{~h}$. Cytotoxicity was evaluated by the MTT test. Values are the mean $( \pm \mathrm{SD})$ of three independent experiments.

tency comparable to that of cisplatin (average $\mathrm{IC}_{50}$ of $19.9,15.3$ and $15.7 \mu \mathrm{M}$ for $[\mathrm{Pd}(\mathrm{ESDT})(\mathrm{dab})]_{n} \mathrm{Cl}_{n},\left[\mathrm{Pd}_{2} \mathrm{Cl}_{2}(\mathrm{ESDT})_{2}(\mathrm{dah})\right]$ and cisplatin, respectively).

Among binuclear Pd complexes, the antiproliferative activity against both cell lines increases when the diamine was 1,7-diaminoeptane, the effect being, also in this case, more evident for the ESDT complex (Fig. 2 and Table 4). The importance of the chain length of the bridging diamine was pointed out in various multicharged polynuclear complexes, the most active species containing 1,6-diaminoexane [10].

Additionally, the most promising derivatives [Pd(ESDT) (dab) $]_{n} \mathrm{Cl}_{n}$ and $\left[\mathrm{Pd}_{2} \mathrm{Cl}_{2} \text { (ESDT) }\right)_{2}$ (dah)], were also tested against a cisplatin-resistant human ovarian carcinoma subline, C13* cells, in order to assess their cross-resistance with cisplatin. In $\mathrm{C} 13^{*}$ cells, cisplatin resistance has been correlated to a reduced cell drug uptake, high cellular thioredoxin reductase and glutathione levels, and enhanced repair of DNA damage [45]. The cytotoxicity of Pd derivatives was assessed in sensitive and resistant cells after 48$\mathrm{h}$ drug exposure by the MTT test; for comparison purposes, the cytotoxicity of cisplatin was also evaluated under the same experimental conditions. Cross-resistance profiles were evaluated by means of the resistance factor (RF), which is defined as the ratio between $\mathrm{IC}_{50}$ values calculated for calculated for cisplatin-resistant cell lines and those arising from the sensitive parental ones (see Table 5). 
Table 5

Cisplatin cross-resistance profiles.

\begin{tabular}{llll}
\hline Compound & \multicolumn{2}{l}{} & \\
\cline { 2 - 4 } & 2008 & $\mathrm{IC}_{50}(\mu \mathrm{M}) \pm \mathrm{SD}$ & $\mathrm{RF}$ \\
\hline$\left[\mathrm{Pd}_{2} \mathrm{Cl}_{2}(\mathrm{ESDT})_{2}(\mathrm{dah})\right]$ & $16.36 \pm 1.14$ & $14.48 \pm 0.95$ & 0.9 \\
$\left.[\mathrm{Pd}(\mathrm{ESDT})(\mathrm{dab})]_{n} \mathrm{Cl}{ }_{n}\right]$ & $18.40 \pm 1.81$ & $17.58 \pm 2.04$ & 0.9 \\
Cisplatin & $12.24 \pm 2.15$ & $95.45 \pm 2.05$ & 7.8 \\
\hline
\end{tabular}

$\mathrm{SD}=$ standard deviation. $\mathrm{IC}_{50}$ values were calculated by probit analysis $\left(P<0.05, \chi^{2}\right.$ test). Cells $\left(3 \times 10^{4} \mathrm{ml}^{-1}\right)$ were treated for $48 \mathrm{~h}$ with increasing concentrations of tested compounds. Cytotoxicity was assessed by MTT test.

Remarkably, both ESTD derivatives exhibited a different crossresistance profile from that of cisplatin, being the RF values calculated for $[\mathrm{Pd}(\mathrm{ESDT})(\mathrm{dab})]_{n} \mathrm{Cl}_{n}$ and $\left[\mathrm{Pd}_{2} \mathrm{Cl}_{2}(\mathrm{ESDT})_{2}(\mathrm{dah})\right]$ about 8 times lower than that of cisplatin. These results, besides attesting for derivatives $[\mathrm{Pd}(\mathrm{ESDT})(\mathrm{dab})]_{n} \mathrm{Cl}_{n}$ and $\left[\mathrm{Pd}_{2} \mathrm{Cl}_{2}(\mathrm{ESDT})_{2}(\mathrm{dah})\right]$ the ability to circumvent the acquired cisplatin resistance, support the hypothesis of a different cytotoxic mechanisms of action for these poly- and binuclear Pd ESDT complexes than that of the reference metallodrug.

\section{Conclusions}

Reaction between dithiocarbamate complexes of the type $[\mathrm{PdCl} \text { (dithiocarbamate) }]_{n}$ and different diamines like "en", "dap", "dab" and "dah" have been investigated. The reactions products depend on either diamine chain length or molar ratio. With the longer "dab" and "dah" the products obtained are dinuclear species of the type $\left[\mathrm{Pd}_{2} \mathrm{Cl}_{2} \text { (dithiocarbamate) }\right)_{2}$ (amine)] or polynuclear species $[\mathrm{PdCl} \text { (dithiocarbamate)(amine) }]_{n} \mathrm{Cl}_{n}$ (Pd/amine molar ratio $1: 0.5$ and $1: 1$, respectively) while anionic species like $[\mathrm{Pd}$ (dithiocarbamate)(diamine) $\mathrm{Cl}$ or exchange ligand reactions occur with the shorter "en" and "dap". An appreciable in vitro antiproliferative activity toward two different cancer cell lines have been obtained with the dinuclear $\left[\mathrm{Pd}_{2} \mathrm{Cl}_{2} \text { (dithiocarbamate) }\right)_{2}$ (amine)] (amine "dah" or "dab"; dithiocarbamate ESDT and PyDT) and polynuclear species. Interestingly, $[\mathrm{Pd}(\mathrm{ESDT})(\mathrm{dab})]_{n} \mathrm{Cl}_{n}$ and $\left[\mathrm{Pd}_{2} \mathrm{Cl}_{2}(\mathrm{ESDT})_{2^{-}}\right.$ (dah)] showed a remarkable cytotoxic activity also toward cisplatin-resistant $\mathrm{C}_{13}{ }^{*}$ cells, thus strengthening the prospective of further studies on this class of non-covalent polynuclear metal complexes.

\section{Acknowledgements}

The authors thank C.I.R.C.M.S.B. (Consorzio Interuniversitario per la Ricerca Chimica dei Metalli nei Sistemi Biologici). We are grateful to Prof. G. Faraglia for the helpful suggestions and to Dr. S. Sitran for the DTA analyses.

\section{References}

[1] (a)B. Lippert (Ed.), Cisplatin-Chemistry and Biochemistry of a Leading Anticancer Drug, VHCA/Wiley-VCH, Zürich/Weinheim, 1999;

(b) K.B. Garbutcheon-Singh, M.P. Grant, B.W. Harper, A.M. Krause-Heuer, M. Manohar, N. Orkey, J.R. Aldrich-Wright, Curr. Top. Med. Chem. 11 (2011) 521.

[2] B. Miller, S. Wild, H. Zorbas, W. Beck, Inorg. Chim. Acta 290 (1999) 237.

[3] M.V. De Almeida, A.P.S. Fontes, R.N. Berg, E.T. César, E.C.A. Felicio, J.D.S. Filho, Molecules 7 (2002) 405.
[4] L. Gude, M.-J. Fernàndez, K.B. Grant, A. Lorente, Bioorg. Med. Chem. Lett. 12 (2002) 3125.

[5] M. Cusumano, A. Giannetto, A. Imbalzano, Polyhedron 17 (1998) 125

[6] (a) M.A. Haj, M. Quiròs, J.M. Salas, J. Chem. Soc., Dalton Trans. (2002) 4740; (b) F.R. Saunders, H.M. Wallace, Biochem. Soc. Trans. 35 (2007) 364.

[7] (a) M.T. Parker, E.W. Gerner, Biochimie 84 (2002) 815; (b) E.W. Gerner, Cancer Prev. Res. 3 (2010) 125.

[8] (a) M.J. Reyes, F. Delgado, M.L. Izquierdo, J. Alvarez-Builla, Tetrahedron 58 (2002) 8573

(b) E.W. Gerner, F.L. Meyskens, Clin. Cancer Res. 15 (2009) 758

[9] (a) Y. Qu, H. Rauter, A.P.S. Fontes, R. Bandarage, L.R. Kelland, N. Farrel, J. Med. Chem. 43 (2000) 3189;

(b) N.J. Wheate, S. Walker, G.E. Craig, R. Oun, Dalton Trans. 39 (2010) 8113.

[10] (a) P. Perego, L. Gatti, C. Caserini, R. Supino, D. Colangelo, R. Leone, S. Spinelli, N. Farrel, F. Zunino, J. Inorg. Biochem. 77 (1999) 59;

(b) R.C. Jiang, W.Y. Choi, L.M. Hui, E.W. Gerner, S.R. Hamilton, W.U. Zhang Cancer Biol. Ther. 6 (2007) 1644.

[11] A. Hegmans, Y. Qu, L.R. Kelland, J.D. Roberts, N. Farrel, Inorg. Chem. 40 (2001) 6108.

[12] B.A.J. Jansen, J. Van der Zwan, H. den Dulk, J. Brouwer, J. Reedijk, J. Med. Chem. 44 (2001) 245

[13] E. Schuhmann, J. Altman, K. Karaghiosoff, W. Beck, Inorg. Chem. 34 (1995) 2316.

[14] J. Reedijk, Chem. Rev. 99 (1999) 2499.

[15] W.J.F. Van der Vijgh, G.J. Peters, Semin. Oncol. 21 (Suppl. 11) (1994) 2.

[16] F. Zunino, G. Protesi, A. Michelon, Chem. Biol. Interact. 70 (1989) 89.

[17] F.P.T. Hamers, C. Pette, B. Bravenboer, Cancer Chemother. Pharmacol. 32 (1993) 162

[18] J.A. Galbraith, K.A. Menzel, E.M.A. Ratilla, N.M. Kostic, Inorg. Chem. 26 (1987) 2073.

[19] I.E. Burgeson, N.M. Kostic, Inorg. Chem. 30 (1991) 4299.

[20] T.G. Appleton, J.W. Connor, J.R. Hall, P.D. Prenzler, Inorg. Chem. 28 (1989) 2030

[21] Z.D. Bugarčic, G. Liehr, R. van Eldik, J. Chem. Soc., Dalton Trans. (2002) 951.

[22] K. Lemma, S.K.C. Elmroth, L.I. Elding, J. Chem. Soc., Dalton Trans. (2002) 1281

[23] J. Landi, M.P. Hacher, N. Farrel, Inorg. Chim. Acta 202 (1992) 79.

[24] E.C.H. Ling, G.W. Allen, T.W. Hambley, J. Chem. Soc., Dalton Trans. (1993) 3705

[25] A. Pasini, G. D’Alfonso, C. Manzotti, M. Moret, Inorg. Chem. 33 (1994) 4140

[26] R. Mital, N. Jain, T.S. Srivastava, Inorg. Chim. Acta 166 (1989) 135.

[27] D. Fregona, S. Tenconi, G. Faraglia, S. Sitran, Polyhedron 16 (1997) 3795.

[28] G. Faraglia, D. Fregona, S. Sitran, L. Giovagnini, C. Marzano, F. Baccichetti, U. Casellato, R. Graziani, J. Inorg. Biochem. 83 (2001) 31.

[29] (a) L. Cattaruzza, D. Fregona, M. Mongiat, L. Ronconi, A. Fassina, A. Colombatti, D. Aldinucci, Int. J. Cancer 128 (2011) 206;

(b) L. Giovagnini, C. Marzano, F. Bettio, D. Fregona, J. Inorg. Biochem. 99 (2005) 2139;

(c) L. Ronconi, L. Giovagnini, C. Marzano, F. Bettio, R. Graziani, G. Pilloni, D. Fregona, Inorg. Chem. 44 (2005) 1867;

(d) X. Zhang, M. Frezza, V. Milacic, L. Ronconi, Y.H. Fan, C Bi, D. Fregona, Q.P. Dou, J. Cell. Biochem. 109 (2010) 162.

[30] C. Marzano, D. Fregona, F. Baccichetti, A. Trevisan, L. Giovagnini, F. Bordin Chem. Biol. Interact. 140 (2002) 215

[31] C. Marzano, A. Trevisan, L. Giovagnini, D. Fregona, Toxicol. In Vitro 16 (2002) 413.

[32] A. Trevisan, C. Marzano, P. Cristofori, M. Borella Venturini, L. Giovagnini, D. Fregona, Arch. Toxicol. 76 (2002) 262.

[33] J. Grant Collins, N.J. Wheate, J. Inorg. Biochem. 98 (2004) 1578.

[34] Y. Qu, A. Harris, A. Hegmans, A. Petz, P. Kabolizadeh, H. Penazova, N. Farrell, J. Inorg. Biochem. 98 (2004) 1591.

[35] H. Daghriri, F. Huq, P. Beale, J. Inorg. Biochem. 98 (2004) 1722.

[36] G. Faraglia, L. Sindellari, S. Sitran, Transition Met. Chem. 19 (1994) 248

[37] G. Faraglia, D. Longo, V. Cerchi, S. Sitran, Polyhedron 14 (1995) 1905.

[38] G. Faraglia, S. Sitran, D. Montagner, Inorg. Chim. Acta 358 (2005) 971.

[39] G. Faraglia, S. Sitran, Inorg. Chim. Acta 176 (1990) 67.

[40] V. Scarcia, A. Furlani, D. Fregona, G. Faraglia, S. Sitran, Polyhedron 18 (1999) 2827

[41] M.C. Alley, D.A. Scudiero, A. Monks, M.L. Hursey, M.J. Czerwinski, D.L. Fine, B.J. Abbott, J.G. Mayo, R.H. Shoemaker, M.R. Boyd, Cancer Res. 48 (1988) 589.

[42] S.C. Nyburg, Acta Crystallogr., Sect. B 52 (1996) 328

[43] S. Marchal, V. Moreno, G. Aullón, S. Alvarez, M. Quirós, M. Font-Bardia, X Solans, Polyhedron 18 (1999) 3675.

[44] D. Montagner, P.J. Sanz Miguel, Dalton Trans. DT-COM-08-2011-011475, accepted for publication.

[45] C. Marzano, V. Gandin, A. Folda, G. Scutari, A. Bindoli, M.P. Rigobello, Free Radic. Biol. Med. 42 (2007) 872. 